\section{Spring Actvities}

\section{Norske koreografer 2: Siri \& Snelle}

Serien Norske koreografer er undervisningsressurser som med utgangspunkt i norske koreografers uttrykk og arbeidsmetoder gir eksempler på øvelser lærere kan benytte i arbeid med kreativt, utforskende, skapende arbeid med elever i skole og lærerutdanning. Den første ressursen i serien omhandlet Jo Strømgrens kunstnerskap, og nå er vi helt i sluttspurten av ferdigstillelsen av ressurs nummer to, med utgangspunkt i kunstnerduoen Siri \& Snelle. Ressursen vil bli tilgjengelig for medlemmer via en innloggingsportal på vår nettside. Vi gleder oss! Følg med!

\section{Styrking av dansekritikk}

I samarbeid med Norsk Tidsskriffforening setter vi i gang kurs i dansekritikk med mulighet for at deltakerne kan få publisert kritikker i vårt tidsskrift Nordic Journal of Dance. Vi er veldig glade for dette samarbeidet med Tidsskriffforeningen og gleder oss til å komme i gang. Mer informasjon om kurs kommer på nyåret når alle detaljer er på plass.

\section{Nettverk for dans i laererutdanning}

Vårt nettverk for dans i lærerutdanning arrangerer webinar med Gunn Engelsrud med tittel «Teoretisk posisjonering» - om konstruksjoner av studenten/ eleven i undervisning i kroppsøving/dans den 15. februar $2022 \mathrm{kl}$. 13-15. Webinaret er åpent for alle interesserte, men påmelding kreves.

Ønsker du å delta på webinaret og/eller bli med i nettverket? Send e-post til sans@dansepraksis.no.

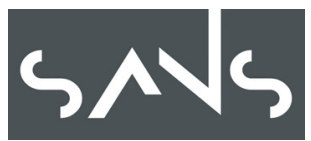

\section{Aksjonen En annen dans}

Siden 2017 har vi hatt en årlig aksjon under Dansens Dager. Aksjonen innebærer at vi sender ut kunstnerpedagoger til skoler i hele landet for å undervise i kreativ dans. Kunstnerpedagogen knytter selv kontakt med en skole i sitt nærmiljø, men honoraret utbetales av SANS.

Lyst til å bli med på aksjonen i 2022? Send CV og kort søknad/motivasjonsbrev til sans@dansepraksis.no.

Frist: 15. januar 2022.

\section{Vårsamling}

Vårsamlingen (vårkurs) blir 6. mai 2022. Det blir som vanlig faglig påfyll, erfaringsutveksling og diskusjon, tilpasset de ulike skoleslag. Vi satser sterkt på å møtes fysisk denne gangen og annonserer innhold så snart dette er på plass, men hold av datoen allerede nå!

Anette Sture Iversen 